\title{
FILOZOFIA W KONTEKŚCIE NAUKI. STARE PROBLEMY W NOWYM WYDANIU
}

\begin{abstract}
Streszczenie. Analizy przeprowadzone w artykule pozwalają na wyciągnięcie wniosków, ważnych dla filozofa przyrody. Między filozofią a naukami przyrodniczymi istnieje interakcja, którą można określić jako współprzenikanie się obu tych dziedzin wiedzy. To współoddziaływanie filozofii z nauką podobne jest do niedomykającego się koła. Trudno jest owo współprzenikanie jednoznacznie scharakteryzować, ale można wskazać pewne idee towarzyszące mu. (1) Uświadomienie sobie filozoficznego uwikłania teorii naukowej powoduje często rozszerzenie jej rozumienia oraz ujawnia, jak wiele informacji zawartych jest w teorii naukowej na temat głębokiej struktury świata. Sformułowanie „filozofia w nauce" można by uznać za charakterystyczne dla współczesnego ujmowania związku filozofii z naukami przyrodniczymi. Należy pamiętać, że wspólna droga filozofii i nauk przyrodniczych pozwala osiągać interesujące poznawczo wyniki, ważne dla rozumienia świata zewnętrznego. (2) Współprzenikanie się filozofii z nauk jest procesem dynamicznym i twórczym. Tak filozofia, jak i nauka, ulegają ciągłym zmianom, które w istotny sposób wpływają na rozwijanie się procesu współprzenikania. Trudno jest przewidywać, w którą stronę ten proces będzie ewoluował. Ważne jest jednak, jak twierdzi M. Heller, aby w tym twórczym procesie dostrzec, że największym sukcesem nauk empirycznych, trwającym do dziś, jest coraz lepsze ugruntowanie się przekonania, że Wszechświat stopniowo, choć tylko w przybliżeniu, ujawnia nam tajemnice swojej struktury.
\end{abstract}

Słowa kluczowe: filozofia przyrody; nauki przyrodnicze; filozofia w nauce.

1. Wstęp - zarys historyczny zagadnienia. 2. Sytuacja aktualna. 2.1. Interdyscyplinarność badawcza. 2.2. Modelowanie przyrody. 3. Powrót filozofii przyrody. 4. Zakończenie. 


\section{WSTĘP - ZARYS HISTORYCZNY ZAGADNIENIA}

Związek filozofii z nauką ${ }^{1}$ był problemem od czasów starożytnych². Filozofia przyrody kształtowała się na styku nauki z filozofią. Do XVII wieku, do czasu usamodzielnienia się nauki, filozofia przyrody była uprawiana w kontekście różnych systemów filozoficznych. Czerpiąc $z$ idei filozoficznych, kształtowano ją w taki sposób, aby była pomocna dla tłumaczenia zjawisk i procesów, zachodzących w świecie przyrody. Stanowiła ona więc swoistą „mieszankę” filozofii z nauką danych czasów. Właściwie była bardziej spekulacją filozoficzną, niż rzeczową refleksją nad światem materialnym. Warto podkreślić, że do XVII wieku nauka nie dysponowała usystematyzowaną refleksją nad metodą naukową. Przyglądając się z perspektywy czasu pierwszym próbom uchwycenia związku filozofii z nauką, należy uznać je za zbyt proste i może naiwne, chociaż mogły one być pożyteczne dla tworzenia obrazu otaczającego świata.

Kształtowanie się naukowego paradygmatu począwszy od XVII wieku nie spowodowało jednak zerwania związku nauki z filozofią. Historia nauki pokazuje, że był to czas, kiedy nauka upomniała się o swoją rolę w tworzeniu obrazu świata ${ }^{3}$. Nowa perspektywa widzenia świata miała oddźwięk w filozofii. Metafizyka zareagowała przypomnieniem poziomów abstrakcji oraz metodologiczną koncepcją nieprzecinających się płaszczyzn badawczych (naukowej i filozoficznej) 4 oraz określając „wkład nauki” jako mało ważny dla

1 Gdy w tekście jest mowa o nauce chodzi o nauki przyrodnicze, zajmujące się rzeczywistością świata materialnego.

2 Mówienie o związku filozofii z nauką ma sens tylko wtedy, gdy przynajmniej w jakieś mierze ukształtowane są nauka i filozofia. Por. L. Russo, Zapomniana rewolucja. Grecka myśl nauka a nauka nowoczesna, tłum. z wł. I. Kania, Wydawnictwo Universitas, Kraków 2005.

3 Por. A.R. Hall, Rewolucja naukowa 1500 - 1800. Kształtowanie się nowożytnej postawy naukowej, tłum. z ang. T. Zambrzuski, Instytut Wydawniczy PAX, Warszawa 1966.

4 Por. M. Heller, Szczęście w przestrzeniach Banacha, Wydawnictwo Znak, Kraków 1995, 18-20. 
filozoficznej refleksji. Nastąpiło starcie między naukowym obrazem świata a filozofią. Musimy jednak pamiętać, że starcie to nie było czymś nowym, gdyż bezkrytyczne powoływanie się na metodologiczną zasadę przestrzegania poziomów badawczych było znane już w średniowieczu ${ }^{5}$. Świat bytów metafizycznych został niejako „oddzielony" od świata rzeczy materialnych. Oddzielenie to określiło tym samym pewną perspektywę badawczą. Ilościowy świat materii nie może wnieść nic interesującego do poznania substancjalnego świata bytów abstrakcyjnych. Wydawać by się mogło, że już w średniowieczu sprawa została ostatecznie rozwiązana. Ale tak się nie stało, o czym świadczą dwie krytyczne sytuacje, do jakich doszło już w 1277 roku (słynne potępienie „tez Arystotelesowskich” przez paryskiego biskupa Tempiera) ${ }^{6}$ oraz w XVI wieku w związku z tzw. „sprawą Galileusza”"

Proces oddzielania się nauki od filozofii powodował coraz silniejsze „oczyszczanie” nauki z filozoficznych „wtrętów”, co w konsekwencji zaczęło stymulować rozwój nauki. Nie była to jednak jedyna przyczyna rozwoju nauki. Nie można zapominać, że największy wpływ na rozwój nauki miała niewątpliwie wypracowana przez naukę metoda matematyczno-empiryczna. Związek matematyki z doświadczeniem stał się czynnikiem fundamentalnym dla strategii badawczej nauk przyrodniczych. Za M. Hellerem można wyrazić naturę tej metody następująco: „Metoda matematycznego modelowania świata - i to już na poziomie mechaniki klasycznej - nie tylko opisuje świat, ale również ujawnia jego ukryte struktury i ich funkcjonowanie. Oczywiście nie można zapominać o drugim filarze metody nowożytnej

5 Por. J. Mączka, Średniowieczny konflikt nauki z teologią. (Potępienie z roku 1277), Analecta Cracoviensia 30-31(1998-1999), 29-36.

6 Przekonanie to było dość powszechne, gdyż towarzyszył mu przede wszystkim niski stan rozwoju nauki oraz przekonanie, że teologia i metafizyka arystotelesowsko-tomistyczna są jedynymi źródłami na kłopoty ze zrozumieniem otaczającej rzeczywistości. Por. J. Mączka, Rozdział rozumu i wiary w XIV wieku, Tarnowskie Studia Teologiczne 20(2001)1, 83-103.

7 Por. Sprawa Galileusza, (wybór i red.) J. Życiński, Wydawnictwo Znak, Kraków 1991; J. Feston, Galileusz, tłum. z ang. A. Szymanowski, Prószyński i S-ka, Warszawa 1998. 
fizyki - o doświadczeniu; bez niego fizyka przestałaby być nauką o świecie. Ale nie można tych dwóch elementów oddzielać od siebie: w metodzie fizyki doświadczenie i matematyka są spojone razem"8.

Rozwój nauki spowodował, że siła impulsów, płynących z nauki do metafizyki, nabierała na znaczeniu i swoje apogeum osiągnęła najpierw w pozytywizmie, a potem w neopozytywizmie. Tym razem, odwołując się tylko do nauki i chcąc określić ostateczne granice sensownej wiedzy, odrzucono metafizykę. Jest rzeczą interesującą, że nauka XX wielu zweryfikowała te rozstrzygnięcia. Okazało się, że były to ślepe zaułki pozytywistycznej filozofii nauki.

Ten krótki rys historyczny ukazuje tak dobrą, jak i złą interakcję, jaka zachodziła między nauką a filozofią. $Z$ jednej strony ludzie nauki zdali sobie sprawę z ograniczeń metody naukowej, z drugiej zauważono skutki odrzucenia filozofii w refleksji nad rozumieniem świata przyrody.

Wydaje się, że najważniejszym osiągnięciem okresu od XVII do $\mathrm{XX}$ wieku było sformułowanie zasadniczych problemów i pytań, ważnych dla dalszej historii tych relacji. Spróbujmy sformułować parę z nich: Czy istnieje sztywna granica między nauką a filozofią? Jeżeli taka granica jest raczej „płynna”, to jakie tematy, problemy, czy miejsca w nauce są twórcze filozoficznie? Jak nauka może wpływać na filozofię, a filozofia na naukę? Jak wygląda obraz świata, kreowany przez naukę, w odniesieniu do filozofii? Czy istnieją granice samej nauki i samej filozofii? Tę listę pytań i problemów można ciągnąć jeszcze dalej', ale już samo ich wyliczenie ma pewien walor filozoficzny. Można zaryzykować stwierdzenie, że ostateczne zamknięcie tej listy pewnie nigdy nie nastąpi, gdyż ani w myśleniu filozoficznym nie widać kresu, ani rozwój nauki nie zakończył się, a nawet trudno przypuszczać, na czym to zakończenie miałoby polegać. Twórczy rozwój filozofii i nauki w przeciągu ostatnich dekad doprowadził do

8 M. Heller, Czy fizyka jest naukq̨ humanistyczną?, Biblos, Tarnów 1998, 36.

9 Por. tamże, 115. 
istotnych zmian zarówno w nauce, jak i w filozofii. Warto przyjrzeć się, na czym one polegały i jak wpłynęły na relację między nauką a filozofią. Umiarkowaną nadzieję na pozytywną odpowiedź należy wiązać z jeszcze jednym pytaniem: czy uda się wskazać drogi, na których ten związek dalej będzie się twórczo rozwijał?

\section{SYTUACJA AKTUALNA}

Nauka na początku XXI wieku stawia filozofię, a filozofię przyrody w szczególności, przed ważnymi wyzwaniami. Obraz świata, inspirowany przez nauki przyrodnicze wraz $\mathrm{z}$ ich matematyczną metodą, w dużym stopniu został dość mocno zróżnicowany. Coraz wyraźniej widać, jak jest trudno wnikać w matematyczną strukturę teorii, a zarazem jak wielkie tkwi w niej bogactwo treści. Wnikanie $\mathrm{w}$ nowe obszary świata sprawiło, że $\mathrm{w}$ tradycyjnych dziedzinach nauki zaczęto wypracowywać coraz bardziej wyrafinowane metody i korzystać z coraz bardziej precyzyjnych badań empirycznych.

\subsection{INTERDYSCYPLINARNOŚĆ BADAWCZA}

Jeżeli wiek XX był zasadniczo wiekiem fizyki, to koniec tego wieku oraz początek XXI wieku zwracają uwagę zwłaszcza na kosmologię, biologię i psychologię. Ich intensywny rozwój rozpoczął się, gdy zauważono, że coraz bardziej zacierają się granice nie tylko między fizyką i chemią, ale również między innymi dziedzinami wiedzy, a coraz silniejsza obecność w nich matematyki otworzyła drogi do nowych badań w nieznanej dotychczas skali. Najwyraźniej widać to na przykładzie kosmologii i biologii ${ }^{10}$.

Historia nauki początku XX wieku pokazuje, że najszybciej granica ta uległa rozmyciu między fizyką a chemią, ale następne lata to wdzieranie się fizyko-chemicznej strategii badawczej w inne

10 Por. tamże, 84-85. 
dziedziny wiedzy. Bez uwzględniania osiągnięć mechaniki kwantowej i fizyki cząstek elementarnych niemożliwe byłoby zrozumienie świata pierwiastków chemicznych i zachodzących tam związków. Można również zadać pytanie: jak wyglądałyby współczesne badania nad ewolucją wszechświata bez ciągle rozwijającej się fizyki cząstek elementarnych. Przede wszystkim sukcesy fizyko-chemicznej strategii w badaniu świata chemii zachęciły do stosowania tej strategii do wyjaśniania zjawisk przyrodniczych z zakresu np. biologii czy nawet psychologii. W tym miejscu należy wspomnieć o refleksji filozoficznej nad tą strategią. W tej refleksji dominuje dziś redukcjonizm. O jego zaletach i wadach dużo już pisano, ale w skrócie można powiedzieć, że redukcjonizm typu ontologicznego czy pojęciowego (sprowadzenie wyjaśnień naukowych do struktur pojęciowych np. fizyki) byłby nie do przyjęcia, natomiast redukcjonizm metodologiczny należy uznać, w pewnych wersjach, za możliwy do przyjęcia ${ }^{11}$. Odrzucenie redukcjonizmu ontologicznego wiąże się $\mathrm{z}$ negowaniem innej rzeczywistości niż np. materialna (głęboki monizm deterministyczny). Możliwość przyjęcia redukcjonizmu metodologicznego postuluje odwołanie się do mechanizmów i procesów, zachodzących w przyrodzie. Początkowo stosowanie metod redukcjonistycznych do biologii i psychologii nie przyniosło wielu rezultatów, ale redukcjonizm ukazał

11 Trzeba jednak zauważyć, że nie wszyscy w ten sam sposób oceniają redukcjonizm. Na przykład John Polkinghorne stwierdził: „nie mam nic przeciwko redukcjonizmowi ontologicznemu, ponieważ jestem zdania, iż jeśli podda się mój organizm analizie, to w końcu dotrze się do kwarków, gluonów i elektronów. Zgadzam się z tym, że ludzie są jednością psychosomatyczną i nie sądzę, iżby rozdzielne składniki duchowe (dusza i entelechia) były częścią naszej konstytucji. (...), przeciwstawiam się redukcjonizmowi pojęciowemu (który twierdzi, że biologia i antropologia nie są niczym innym, jak tylko rozbudowanymi tezami fizyki)" (J. Polkinghorne, Prawa natury i prawa fizyki, w: Stwórca - Wszechświat Człowiek. Wybór tekstów wygłoszonych podczas cyklu konferencji „Boże działanie w perspektywie nauki" zorganizowanego przez Watykańskie Obserwatorium Astronomiczne (Specola Vaticana) oraz Center for Theology and the Natural Science (CTNS; Berkeley, Kalifornia): 1988-2001, red. M. Heller, T. Sierotowicz, tłum. z ang. T. Sierotowicz, t. 1, OBI - Biblos, Kraków - Tarnów 2006, 201). 
swoją siłę, otwierając szerzej drzwi dla strategii badawczej, którą zaczęto nazywać interdyscyplinarnością ${ }^{12}$. Nie jest ona zupełnie nową strategią, ale trzeba przyznać, że w XX wieku rozwinęła się bardzo znacząco, odnosząc wiele sukcesów.

Przełom wieku XX i XXI pokazuje, że interdyscyplinarna strategia prowadzonych badań postąpiła naprzód. Przede wszystkim zaczęła o wiele skuteczniej obejmować swoim zasięgiem wiele nowych dziedzin wiedzy. Ale stało się coś więcej. Co prawda w jej zasięgu była już jakoś obecna filozofia, ale dopiero poprzez badania z zakresu filozofii nauki interdyscyplinarność stała się bardziej obecna w filozofii przyrody. Rozpoczął się ważny etap w rozwoju relacji między nauką a filozofią. Doprowadził on do ukształtowania się stylu myślenia, który nazywa się „filozofią w nauce”. Zauważono, że filozoficzny punkt widzenia, zawarty w badaniach naukowych, w istotny sposób uzupełnia i wzmacnia refleksję filozoficzną.

Ważnym osiągnięciem filozoficznej refleksji nad interdyscyplinarnością jest uświadomienie sobie zasad nią rządzących. Niektóre z tych zasad były znane od dawna, m.in.: przyjmując współoddziaływanie poziomów naukowych, należy zachować kompetencje przedmiotowe każdej z dziedzin wiedzy oraz przestrzegać zakresów, wyznaczanych przez ich metodę naukową. Zasady te pozwalają uniknąć przynajmniej dwóch niebezpieczeństw: (1) nieuprawnionego redukcjonizmu oraz (2) prostej, przedmiotowej ekstrapolacji tematów z jednej dziedziny wiedzy do drugiej ${ }^{13}$.

Interdyscyplinarną strategię trzeba ciągle mieć na uwadze, gdy uprawia się „filozofię w nauce”. Rzuca to też pewne światło na pytanie o istnienie granicy między filozofią a nauką. Mówiąc krótko, granice te ulegają swoistemu rozmyciu, ale nie „wymieszaniu”.

12 Por. np. M. Walczak, Czy możliwa jest wiedza interdyscyplinarna?, Zagadnienia Naukoznawstwa 207(2016)1, 113-126.

13 Interdyscyplinarność nie jest jednak panaceum na rozwiązanie wszystkich problemów naukowych i filozoficznych. Należy zawsze uważać, aby pod pozorem interdyscyplinarności nie utracić tych wartości, jakie wnoszą poszczególne dyscypliny. 
Interdyscyplinarność wymaga podwójnego udziału filozofii w badaniach naukowych: $z$ jednej strony filozofia (filozofia przyrody) pozwala lepiej uchwycić związek teorii naukowych z przyrodą, z jej głęboką strukturą, a $z$ drugiej strony refleksja czyniona $z$ pozycji „meta”, tj. z pozycji filozofii nauki, umożliwia kontrolowanie przestrzegania zasad metodologicznych, a w konsekwencji aproksymacyjnego przybliżania się do prawdy o świecie przyrody.

\subsection{MODELOWANIE PRZYRODY}

Charakteryzując współczesne tendencje interdyscyplinarne, nie można zapomnieć o matematyce. Właściwie to zastosowanie matematyki do poszczególnych dziedzin nauki umożliwiło szybki rozwój interdyscyplinarności. Jak zauważa M. Heller, „matematyczne modelowanie przyrody jest faktem" 14 . Nauka zmierza w kierunku coraz szerszego wykorzystania matematyki i ta tendencja wydaje się być niezachwiana. Ale nie jest tak, że matematyka stanie się kluczem dla rozwiązani wszystkich rodzących się problemów ${ }^{15}$.

Rozważmy pytanie: skąd bierze tak daleko idąca skuteczność matematycznego „opisu”? W pytaniu tym chodzi o wzajemne współoddziaływania filozofii $z$ nauką. Poszukiwanie odpowiedzi na to pytanie poprowadźmy dwiema drogami, rozważymy mianowicie: (1) matematykę (jako język i strukturę teorii naukowych, dzięki którym

14 M. Heller, Uchwycić przemijanie, Wydawnictwo Znak, Kraków 1997, 15; por. także E. Wigner, Niepojęta skuteczność matematyki w naukach przyrodniczych, w: Refleksje na rozdrożu. Wybór tekstów z pogranicza wiedzy i wiary, red. S. Wszołek, OBI - Biblos, Kraków - Tarnów 2000, 237-249.

15 Często wskazuje się na twierdzenie Gödla jako na poważne ograniczenie, tkwiące w samej matematyce. „Twierdzenie Gödla stwierdza, że nie istnieje układ założeń (aksjomatów) i reguł wnioskowania wystarczająco silny, by udowodnić wszystkie prawdziwe twierdzenia arytmetyki, który nie byłby równocześnie wystarczająco silny, by 'udowodnić' również twierdzenia fałszywe. Jeżeli odnosi się to do arytmetyki, to odnosi się to również do każdego układu aksjomatów i reguł wnioskowania, który obejmuje arytmetykę" (M. Heller, Uchwycić przemijanie, dz. cyt., 234-235). 
można sięgnąć do głębokiej struktury rzeczywistości); (2) dynamikę struktury matematycznej.

Rozpoczynając kroczenie po pierwszej z tych dróg, musimy zastanowić się nad kwestią: czy matematyka jest tylko językiem teorii naukowych, czy też czymś więcej? Przyglądając się teoriom fizycznym, możemy stwierdzić, że każda teoria składa się: (A) z matematycznej struktury; (B) z dziedziny teorii, która stanowi, ogólnie rzecz biorąc, ten aspekt czy też obszar świata, do którego teoria się odnosi; (C) z reguł mostowych, łączących (A) z (B) - reguły te są czasem zwane definicjami koordynującymi albo (w węższym sensie) interpretacjami (A). Niekiedy mówi się, że (A) jest modelem (B) ${ }^{16}$. Te trzy elementy teorii fizycznej (schemat ten może przekładać się na teorie innych nauk) stanowią pewną organiczną jedność, ale ten „suchy” schemat nie ukazuje w pełni wszystkich niuansów, związanych z całościową strukturą teorii. Nigdy nie mamy od razu gotowej struktury matematycznej danej teorii ${ }^{17}$, nigdy też nie jest od razu wyraźnie określona dziedzina teorii ${ }^{18}$, a i reguły mostowe nie są „z pewnością jednoznacznymi definicjami koordynującymi, lecz zwykle są uwikłane w niuanse struktury matematycznej tak, że ich

16 Por. M. Heller, O teologicznych interpretacjach fizycznych teorii stworzenia, w: Stwórca - Wszechświat - Człowiek, dz. cyt., 187. Warto zwrócić uwagę na przypis 2 do powyższego cytatu.

17 „Zazwyczaj pełna struktura matematyczna danej teorii fizycznej znana jest dopiero wtedy, kiedy zostanie zaproponowana nowa, ogólniejsza teoria fizyczna, to jest kiedy granice zastosowania starej teorii są już doskonale znane. Na przykład pełna matematyczna (geometryczna) struktura klasycznej mechaniki została odkryta po opracowaniu geometrycznych szczegółów ogólnej relatywistycznej struktury czasoprzestrzeni (przez Cartana i innych)" (tamże, 188).

18 „Ściśle rzecz biorąc, jedynym wiarygodnym źródłem wiedzy na temat domeny teorii są wyniki eksperymentów, które nie są niezależne od matematycznej struktury teorii (bez takiej struktury nie wiedzielibyśmy, co mierzymy, jak mierzyć należy i jak trzeba interpretować to, co zostało zmierzone). Tego rodzaju wyniki stanowią tylko pewien aspekt rzeczywistości, to jest informują nas o wierzchołku góry lodowej, której reszta pozostaje poza naszym zasięgiem" (tamże). 
referencje są czasem wieloznaczne"19. Pomimo wymienionych zastrzeżeń schemat ten dosyć dobrze ujmuje to, co zwykle rozumie się przez teorię naukową. W ten sposób otrzymujemy model matematyczny badanej rzeczywistości, który choć nie jest jednoznaczną kopią rzeczywistości, to jest zadziwiająco „skutecznym” jej ujęciem.

Matematyka jest nie tylko językiem, którym posługują się teorie naukowe. Trzeba uwzględnić jeszcze jeden czynnik. M. Heller stwierdza: „konstruując matematyczne teorie świata, włączmy w nie informacje, które udało się uzyskać za pomocą połączenia wysiłków poprzednio dokonanych doświadczeń i uprzednio skonstruowanych teorii. A jednak nasze struktury teoretyczne dają nam więcej informacji w porównaniu z ilością informacji zainwestowanej. Można odnieść wrażenie, że nasze matematyczne teorie nie tylko są rodzajem maszyny przetwarzającej informacje, lecz także rodzajem maszyny tworzącej informacje" 20 . Można powiedzieć jeszcze więcej, struktura matematyczna nie tylko przetwarza informacje, ale je również tworzy. Są to informacje o głębokiej strukturze świata. Ujawnia się tu jeden ze sposobów uwikłania filozofii w struktury o charakterze matematycznym. „Metoda matematycznego modelowania świata $i$ to już na poziomie mechaniki klasycznej - nie tylko opisuje świat, ale również ujawnia pewne ukryte struktury $i$ ich funkcjonowanie" 21 . Modelowanie świata bardzo często ujawnia to, co jest „ukryte”, czego nie widać „na powierzchni”. Potrzeba namysłu czy konfrontacji z doświadczeniem, aby ujawnić niewidoczne elementy matematycznej struktury. Część niewidocznych elementów wymaga jeszcze innego „narzędzia”. Potrzebna jest filozofia, aby niejako wskazała na ukrytą ontologię świata wraz jej „obiektami”22. Mówimy, że struktura ma-

19 Tamże, 189.

20 M. Heller, Chaos, prawdopodobieństwo i pojmowalność świata, w: Stwórca - Wszechświat - Człowiek, dz. cyt., 252-253.

21 Tenże, Czy fizyka jest nauka humanistyczną?, dz. cyt., 36.

22 Słowo obiekt zostało ujęte w cudzysłów, gdyż trudno byłoby dać jednoznaczne określenie, czym on jest. W jakimś sensie jest to obiekt realny, który oprócz składowej podatnej na 
tematyczna „dociera” do głębokiej struktury świata, do której sama filozofia, bez pomocy matematyki, nie byłaby w stanie dotrzeć.

$Z$ kolei gdy chodzi o dynamikę struktury matematycznej, należy zauważyć, że rzeczywistość, która podlega modelowaniu, nie jest zbiorem prostych, statycznych, liniowych procesów. Prosta obserwacja otaczającego nas świata podpowiada, że jest to świat dynamiczny. Jawi się on człowiekowi jako zmienny. Mechanika klasyczna poradziła sobie ze zmiennością, stosując do jej badania rachunek różniczkowy i całkowy ${ }^{23}$, ale współczesne oblicza zmienności są o wiele trudniejsze do uchwycenia. Dzisiaj zmienność często łączy się z typem zjawisk fizycznych, zwanych chaosem. Czy chaos ulega matematyzacji? Owszem, zarówno matematycy, jak i fizycy radzą sobie $z$ tym problem bardzo dobrze. $Z$ pomocą przyszła im matematyczna teoria układów dynamicznych. Zapoczątkowana jeszcze przez Poincarégo, rozwijana przez matematyków i fizyków XX wieku, dziś uzyskała status rozwiniętej teorii. „Z chaosem dynamicznym mamy do czynienia wówczas, gdy równanie (lub równania) opisujące dany proces mechaniczny, wykazują szczególną wrażliwość na małą zmianę warunków początkowych. (...) Teoria 'układów dynamicznych z chaosem' spowodowała w dwudziestowiecznej fizyce rewolucję tam, gdzie się jej najmniej spodziewano, a mianowicie w mechanice klasycznej. (...) Odkrycie, że dotychczas znano jedynie 'bardzo rzadkie' układy bez chaosu i że 'prawie wszystko' w mechanice jest chaotyczne, było prawdziwym zaskoczeniem" 24 . Matematyczna struktura zjawisk chaotycznych pociągnęła za sobą daleko idące konsekwencje i to nie tylko na polu fizyki. Ogólny schemat teorii naukowej uzyskał dodatkową własność, ,jedność dynamiczna, [która - J.M.] podlega ewolucji i ma swoją historię"25. Co prawda teoria układów chao-

metodę naukową, zawiera również bogatą w treść składową filozoficzną.

23 Por. M. Heller, Uchwycić przemijanie, dz. cyt.

24 Tamże, 228-229.

25 M. Heller, O teologicznych interpretacjach fizycznych teorii stworzenia, dz. cyt., 187. 
tycznych jest ważnym osiągnięciem, ale nie jest jeszcze tak, że oto dostaliśmy teorię radzącą sobie $\mathrm{z}$ każdym typem zmienności, jaki jest obecny w przyrodzie. Pojawiają się tu również pewne ograniczenia. Musimy pamiętać, że teoria układów dynamicznych nadal jest tylko przybliżeniem głębokiej struktury rzeczywistości. Co więcej: „Wiele poważnych racji wskazuje na to, że nieliniowe, a nawet niecałkowalne równania, chaos deterministyczny i wiele innych 'dużo bogatszych' od arytmetyki struktur są nie tylko kwestią wygody rachunkowej, lecz stanowią istotne elementy architektury Wszechświata. Jeżeli tak, to świat nie jest tylko 'szybkim liczydłem', lecz 'fizycznie zinterpretowaną' strukturą matematyczną, do której odnoszą się wszystkie ograniczenia związane z twierdzeniem Gödla"26.

Aby ukazać związek teorii chaosu z filozofią, przytoczmy przykład, jaki analizował John Polkinghorne. Uważa on, że możliwa jest taka interpretacja teorii chaosu, która może być pomocna przy analizowaniu pojęcia „stawania się”. Układ, nawet niezbyt złożony, może wykazywać dużą niestabilność, a w konsekwencji nieprzewidywalność. Nieprzewidywalność nie jest całkowita, lecz jedynie statystyczna, ale i tak na tyle duża, że ma znaczenie epistemologiczne (trudno mieć pewność, że zebraliśmy wszystkie potrzebne dane do zrekonstruowania badanej struktury), a nawet ontologiczne (tkwi w naturze przyrody). Musimy cały czas pamiętać, że jesteśmy w obszarze fizyki klasycznej. Na płaszczyźnie fizyki klasycznej nieprzewidywalność jest ograniczeniem, które jest nieprzezwyciężalne. Polkinghorne sugeruje, że być może potrzebna jest „nowa fizyka”, aby zaradzić nieprzewidywalności. Rzecz polega na tym, aby zaangażować do rozwiązania tego problemu teorię chaosu i za jej pomocą zdefiniować nowość czy właśnie stawanie się. „Przyszłość w historii wszechświata jest prawdziwą nowością i prawdziwym stawaniem się"27. Na czym ta nowość i stawanie miałyby polegać? Wychodząc

26 Tenże, Uchwycić przemijanie, dz. cyt., 235.

27 J. Polkinghorne, Prawa natury i prawa fizyki, dz., cyt., 206. 
z założenia, że świat fizyczny jest otwarty i nie jest loterią przypadków, Polkinghorne zauważa, że można przyjąć, bazując na teorii deterministycznego chaosu, istnienie regulujących praw i zasad, których nie można całkowicie sprowadzić do praw fizyki, a które to prawa i zasady odpowiedzialne byłyby za wyłanianie się nowości. Nowość nie byłaby wynikiem tylko innego ustrukturalizowania dotychczasowych praw, ale również wkraczałaby w nią ,aktywna informacja”. Źródłem tej „aktywnej informacji” może być tkwiąca w naturze przyrody jej wolność. Nie dowolność, ale swoista wolność. „Można interpretować owe ogólne formy 'aktywnej informacji', jako odpowiadające działaniom będącym wyrazem wolności. Oznacza to, że nawet formy niższego rzędu (organizujące zasady) mogą doprowadzić do zaistnienia wcześniej niezrealizowanych możliwości będących autentyczną nowością (na przykład zaistnienie życia) i w konsekwencji do zaistnienia fenomenu stawania się, co zdaje się być oczywistą cechą tak biologicznej, jak i kosmologicznej historii. Inne aspekty stawania się mogą być modelowane za pośrednictwem samoorganizujących się zachowań systemów odległych od stanów równowagi, kiedy to niewielkie zaburzenie może doprowadzić do ustalenia się porządku w skali makroskopowej. (...) Otwiera się zatem logiczna możliwość, ale nie konieczność, dania pierwszeństwa nie równaniom, ale zachowaniom. Tym sposobem deterministyczny chaos staje się dla współczesnej fizyki znakiem istnienia świata subtelnych i elastycznych wielkości, których prawa nie zostały jak dotąd odkryte, zaś obecnie znane podstawowe prawa są ich asymptotycznym przybliżeniem" 28 . Wydaje się, że nie tylko dobra znajomość teorii deterministycznego chaosu, lecz również filozoficzne wyrobienie pomogły przywołanemu autorowi w sformułowaniu ciekawych wniosków.

Poszukiwania Polkinghorne’a są przykładem współdziałania filozofii z konkretną teorią fizyczną $\mathrm{w}$ dochodzeniu do lepszego rozumienia pojęcia stawania się (nowość). Takich przykładów można

28 Tamże, 207-208. 
przytoczyć dużo więcej. Ważne jest jednak to, że współoddziaływanie filozofii z nauką jest żywe i owocne.

\section{POWRÓT FILOZOFII PRZYRODY}

Historia filozofii dość łatwo pozwala zrekonstruować koleje filozofii przyrody ${ }^{29}$. Dzisiaj możemy powiedzieć, że okres ograniczania jej pola działania, czy wręcz jej eliminacji, już przeminął, a nadszedł czas jej wrastającego znaczenia. Jednym z powodów tej przemiany było uświadomienie sobie granic badawczych, jakie pojawiają się zwłaszcza w obrębie filozofii nauki oraz przedmiotu i strategii działania samej filozofii przyrody. Ta sytuacja sprawiła, że badania, prowadzone przez filozofów przyrody, zyskują na znaczeniu. Wnikając w świat przyrody, filozofowie coraz jaśniej uświadamiają sobie potrzebę ontologii. Właściwie można wskazać na dwa tego powody. Jednym $\mathrm{z}$ nich jest to, że sama przyroda zawsze niesie ze sobą jakąś ontologię, która często wyrasta $\mathrm{z}$ doświadczenia potocznego czy nawet empirycznego. Drugi powód zainteresowania zagadnieniami ontologicznym wynika $\mathrm{z}$,informacji” zawartej w konkretnej strukturze danej teorii naukowej. Można powiedzieć, że w danej teorii naukowej jest zawsze zawarta w sposób naturalny jakaś ontologia. Wydaje się, że jej obecność wynika z bliskości lub wręcz z „przenikania” przez daną teorię naukową rzeczywistej natury świata. Poniżej postaram się uzasadnić, że nie jest to tylko wyraz filozoficznej wiary, ale ma to swoje uzasadnienie w naturze naukowych teorii ${ }^{30}$.

29 Por. M. Heller, Filozofia przyrody. Zarys historyczny, Wydawnictwo Znak, Kraków 2004.

30 Jednym z argumentów na rzecz wzbudzania zaufania dla określonej filozofii oraz bycia obiecującą ontologią jest fakt, że „doktryna filozoficzna ujawnia swoją obecność (lub nieobecność) w teoriach naukowych; i to niezależnie od takich czy innych przekonań twórców tych teorii (a więc poza kontekstem odkrycia), a niekiedy nawet wbrew takim przekonaniom. Teoria empiryczna może być lub nie być fizycznym modelem takiej lub innej doktryny filozoficznej. Jest to jej cechą obiektywną, którą można badać nowoczesnymi środkami formalnymi” (M. Heller, Szczęście w przestrzeniach Banacha, dz. cyt., 25-26). 
Już na wstępie trzeba jasno zauważyć, że nie należy oczekiwać jednej uniwersalnej ontologii. Należy raczej spodziewać się dość dużej ontologicznej różnorodności. Podstawowym problemem jest pytanie: jak wygląda ontologiczne zaangażowanie nauki?

Warto odwołać się do poglądów W. van Quine’a, które zwarł w książce pt: $Z$ punktu widzenia logiki. Pisze tam: „problem jest obecnie wyraźniejszy niż dawniej, dysponujemy bowiem ściślejszymi kryteriami, kryteriami w oparciu o które można ustalić, jaka ontologia jest konsekwencją danej teorii czy danego sposobu mówienia: teoria mianowicie zakłada istnienie tych i tylko tych bytów, których występowanie wśród wartości zmiennych kwantyfikacji tej teorii jest koniecznym warunkiem prawdziwości jej twierdzeń" 31 . Quine'a interesuje więc nie to, co istnieje, lecz to, co za istniejące jest przyjmowane $^{32}$. A więc chodzi o to, co zakłada język danej teorii naukowej. Pogląd Qunie'a pozostaje w opozycji do ontologii typu fenomenalistycznego, instrumentalistycznego oraz "pozytywistycznego", które - stosując skrajny redukcjonizm - odrzucały inne niż tylko zjawiskowe tłumaczenia świata zewnętrznego. Dzięki takim zabiegom fizyka stawała się swoistą ontologią świata ${ }^{33}$.

$\mathrm{Z}$ ontologią teorii naukowych wiąże się kwestia stosunku realizmu teoriopoznawczego do ontologicznego zaangażowania nauki. Czy trzeba przyjąć realizm w sensie naukowym, aby można było sensownie mówić o ontologii teorii naukowej? Należy się przychylić do pozytywnej odpowiedzi. „Teza realizmu naukowego stwierdza jedynie, że istnieje coś, co zasługuje na miano 'obiektywnej rzeczywistości' i że teorie współczesnej nauki trafnie tę rzeczywistość przybliżają" ${ }^{4}$. Stwierdzenie to jest bardzo ważne, gdyż oddaje jedna z najważniejszych cech ontologicznego uwikłania teorii naukowej.

31 W. van O. Quine, Z punktu widzenia logiki, tłum. z ang. B. Stanosz, PWN, Warszawa 1969, 26.

32 Tamże, 29.

33 M. Heller, Czy fizyka jest nauką humanistyczną?, dz. cyt., 80-81, 85.

34 Tenże, Nauka i wyobraźnia, Wydawnictwo Znak, Kraków 1995, 139. 
Struktura teorii naukowej przybliża nas do rzeczywistej struktury świata. Warto w tym miejscu przytoczyć argumenty E. MacMullina na rzecz realizmu naukowego. „Podstawowym roszczeniem naukowego realizmu (...) jest twierdzenie, że długofalowy sukces naukowej teorii daje podstawę do wierzenia, że coś takiego jak byty i struktury rzeczywiście istnieją. W twierdzenie to wbudowane są cztery ważne kwalifikacje: 1) teoria winna odnosić sukcesy w ciągu znacząco długiego okresu; 2) sukces teorii w wyjaśnianiu stanowi pewną rację, choć nie zniewalającą, by w tę teorię wierzyć; 3) wiara w teorię jest wiarą $\mathrm{w}$ to, że teoretyczne struktury są podobne do struktur rzeczywistości; 4) nie głosi się niczego na temat jakiejś specjalnej czy bardziej podstawowej, czy uprzywilejowanej formy istnienia bytów postulowanych"35. W wypowiedzi MacMullina podkreślony jest aspekt strukturalnego wyjaśniania. Chcąc lepiej wniknąć w proces strukturalnego wyjaśnia, należy związać go z ogólnym modelem teorii naukowej, w którym struktura matematyczna jako jej element nabiera wyjątkowego w tym kontekście znaczenia ${ }^{36}$. Coraz częściej mówi się, że „teorie naukowe są po prostu strukturami matematycznymi, zinterpretowanymi jako struktury świata" 37 .

35 E. MacMullin, A Case for Scientific Realism, w: Scientific Realism, red. J. Leplin, University of California Press, Berkeley 1984, 26; zob. także M. Heller, Nauka i wyobraźnia, dz. cyt. 137.

36 Uzasadniając wartość wyjaśniania strukturalnego należy stwierdzić, że „z jednej strony, odznacza się płodnością w tłumaczeniu znanych już danych obserwacyjnych i obserwacyjnym przewidywaniu nowych, ale, z drugiej strony, pewną otwartością czy twórczością: odkrywane struktury okazują się na tyle plastyczne, że bardzo często niejako dostosowują się do anomalii doświadczalnych, jakie w tym czasie mogą się pojawić, a niekiedy same podpowiadają następny krok w teoretycznych dociekaniach. Co więcej, proces odkrywania struktur, mimo ich częstych modyfikacji, a czasem daleko idących ulepszeń, jest procesem o znacznej ciągłości. Ciągłość ta okazuje się następstwem wyżej wspomnianej otwartości modeli: struktury odkrywane przez teorie fizyki czy chemii wydają się podlegać ewolucji w kierunku o coraz większej mocy wyjaśniającej” (M. Heller, Nauka i wyobraźnia, dz. cyt., 138).

37 Por. P. Roman, Some Modern Mathematics for Physicists and Other Outsiders, t. 1, Pergamon Press, Oxford 1975, XXIV (szczególnie przypis 1). 
Dotarliśmy do sedna odpowiedzi na pytanie o ontologiczne zaangażowanie teorii naukowej. Należy stwierdzić, że nauka, a szczególnie fizyka, suponują ontologię strukturalistyczną. Należy zatem zgodzić się z Hellerem, który uważa, że „struktura (teorii naukowej) ma naturę logiczną nie tylko w tym sensie, że jest zbiorem reguł rządzących naukowym dyskursem, ale przede wszystkim w tym sensie, że ujawnia ona logiczną naturę rzeczywistości"38. Mając na uwadze bogactwo otaczającej nas rzeczywistości oraz to, że różne struktury matematyczne wykorzystywane są przez teorie fizyczne do modelowania świata, należy oczekiwać nie jednej ontologii, lecz wielu ontologii strukturalistycznych. Dalsza droga badawcza powinna polegać na dokładnym analizowaniu konkretnych teorii. „Żadna filozofia nie powinna być w szczegółach programowana a priori, lecz po prostu rozwijana przez stawianie i, o ile (jest to) możliwe, rozwiązywanie problemów"39. Myślę, że ta strategia badawcza powinna wyznaczać dalszy rozwój współczesnej filozofii przyrody.

\section{ZAKOŃCZENIE}

Powyższe analizy pozwalają na wyciągnięcie wniosków ważnych dla filozofa przyrody. Między filozofią a nauką istnieje interakcja, którą można określić jako współprzenikanie się obu tych dziedzin wiedzy. To współoddziaływanie filozofii z nauką podobne jest do niedomykającego się koła. „Rozpoczynając pracę w ramach pewnych teorii naukowych, przyjmujemy pewne hipotezy filozoficzne. Ważne jest to, iż mają to być hipotezy, a nie pewniki filozoficzne, i to być może nawet hipotezy robocze. Wykorzystując te hipotezy, opracowujemy w ramach danych teorii naukowych pewien filozoficznie interesujący problem. Wyniki naszej pracy mogą bądź wzmacniać wyjściowe hipotezy filozoficzne, bądź doprowadzać do ich modyfikacji. Proces

38 M. Heller, Czy fizyka jest nauka humanistyczną?, dz. cyt., 107.

39 Tamże, 122. 
ten może powtarzać się wielokrotnie"40. Trudno jest owo współprzenikanie jednoznacznie scharakteryzować, ale można wskazać pewne idee, towarzyszące mu.

(1) Niewątpliwie teorie naukowe „niosą” pewną filozofię. Uświadomienie sobie filozoficznego uwikłania teorii naukowej powoduje często rozszerzenie jej rozumienia oraz ujawnia, jak wiele informacji na temat głębokiej struktury świata zawarte jest w teorii naukowej. Sformułowanie „filozofia w nauce” można by uznać za charakterystyczne dla współczesnego ujmowania związku filozofii z nauką. Należy pamiętać, że wspólna droga filozofii i nauki pozwala osiągać ciekawe wyniki, ważne dla rozumienia świata zewnętrznego.

(2) Współprzenikanie się filozofii z nauką jest procesem dynamicznym i twórczym. Tak filozofia, jak i nauka ulegają ciągłym zmianom, które w istotny sposób wpływają na rozwijanie się procesu współprzenikania. Trudno jest przewidywać, w którą stronę ten proces będzie ewoluował. Ważne jest jednak, aby w tym twórczym procesie dostrzec, że „największym sukcesem nauk empirycznych - sukcesem trwającym od początku czasów nowożytnych do dziś - jest coraz lepsze ugruntowanie się przekonania, że Wszechświat stopniowo, choć tylko w przybliżeniu, ujawnia nam tajemnice swojej struktury"41.

$\mathrm{Na}$ koniec jeszcze jedna istotna uwaga. Rzeczywista wartość filozofii przyrody nie ujawnia się tylko poprzez meta-spekulacje nad jej sposobem uprawnia, ale również po prostu poprzez jej faktyczne uprawianie.

\section{BIBLIOGRAFIA}

Feston J., Galileusz, tłum. z ang. A. Szymanowski, Prószyński i S-ka, Warszawa 1998.

40 Tamże.

41 M. Heller, Nauka i wyobraźnia, dz. cyt., 144. 
Hall A.R., Rewolucja naukowa 1500 - 1800. Ksztattowanie się nowożytnej postawy naukowej, tłum. $z$ ang. T. Zambrzuski, Instytut Wydawniczy PAX, Warszawa 1966.

Heller M., Chaos, prawdopodobieństwo i pojmowalnośćswiata, w: Stwórca-Wszechswiat - Cztowiek. Wybór tekstów wygtoszonych podczas cyklu konferencji „Boże dziatanie w perspektywie nauki” (CTNS; Berkeley, Kalifornia): 1988-2001, red. M. Heller, T. Sierotowicz, tłum. z ang. T. Sierotowicz, t. 1, OBI - Biblos, Kraków - Tarnów 2006, 252-273.

Heller M., Czy fizyka jest nauką humanistyczna?, Biblos, Tarnów1998.

Heller M., Filozofia przyrody. Zarys historyczny, Wydawnictwo Znak, Kraków 2004.

Heller M., Kosmologia i rzeczywistość, Analecta Cracoviensia 20(1988), 15-29.

Heller M., Nauka i wyobraźnia, Wydawnictwo Znak, Kraków 1995.

Heller M., O teologicznych interpretacjach fizycznych teorii stworzenia, w: Stwórca - Wszechświat-Cztowiek. Wybór tekstów wygtoszonych podczas cyklu konferencji „Boże dziatanie w perspektywie nauki” (CTNS; Berkeley, Kalifornia): 1988-2001, red. M. Heller, T. Sierotowicz, thum. z ang. T. Sierotowicz, t. 1, OBI - Biblos, Kraków - Tarnów 2006, 186-199.

Heller M., Szczęście w przestrzeniach Banacha, Wydawnictwo Znak, Kraków 1995. Heller M., Uchwycić przemijanie, Wydawnictwo Znak, 1997.

MacMullin E., A Case for Scientific Realism, w: Scientific Realism, red. J. Leplin, University of California Press, Berkeley 1984, 8-40.

Mączka J., Rozdziat rozumu i wiary w XIV wieku, Tarnowskie Studia Teologiczne 20(2001)1, 83-103.

Mączka J., Średniowieczny konflikt nauki z teologią. (Potępienie z roku 1277), Analecta Cracoviensia 30-31(1998-1999), 29-36.

Polkinghorne J., Prawa natury i prawa fizyki, w: Stwórca - Wszechświat-Cztowiek. Wybór tekstów wygtoszonych podczas cyklu konferencji „Boże dziatanie w perspektywie nauki" (CTNS; Berkeley, Kalifornia): 1988-2001, red. M. Heller, T. Sierotowicz, tłum. z ang. T. Sierotowicz, t. 1, OBI - Biblos, Kraków - Tarnów 2006, 200-215.

Quine W. van O., Z punktu widzenia logiki, tłum. z ang. B. Stanosz, PWN, Warszawa 1969.

Roman P., Some Modern Mathematics for Physicists and Other Outsiders, t. 1, Pergamon Press, Oxford 1975.

Russo L., Zapomniana rewolucja. Grecka myśl nauka a nauka nowoczesna, tłum. z wł. I. Kania, Wydawnictwo Universitas, Kraków 2005.

Sprawa Galileusza, red. J. Życiński, Wydawnictwo Znak, Kraków 1991. 
Walczak M., Czy możliwa jest wiedza interdyscyplinarna?, Zagadnienia Naukoznawstwa 207(2016)1, 113-126.

Wigner E., Niepojęta skutecznośc matematyki w naukach przyrodniczych, w: Refleksje na rozdrożu. Wybór tekstów z pogranicza wiedzy i wiary, red. S. Wszołek, OBI - Biblos, Kraków - Tarnów 2000, 237-249.

\section{PHILOSOPHY IN THE CONTEXT OF SCIENCE. OLD PROBLEMS IN A NEW FORM}

Abstract. The analysis carried out in this article allows one to draw important conclusions from the point of view of the philosopher of nature. There is an interaction between philosophy and science that takes the form of a mutual permeation in a circle that does not close. Although it is hard to characterize such a circle, one can point to some of its accompanying ideas: (1) Understanding the philosophical implications of a scientific theory improves its explanatory power and reveals the information it contains on the fundamental structure of the Universe. The expression "philosophy in science" characterizes the contemporary approach to the relations between philosophy and science. It must be emphasized that the traditional approach of philosophy and science leads to interesting results, important for the understanding of the external world. (2) The mutual permeation of philosophy and science is a dynamic and creative process. Both science and philosophy change constantly, which substantially influence the development of this permeation. It is hard to predict, however, in which direction the process will evolve.

Keywords: philosophy of nature; natural sciences; philosophy in science

\footnotetext{
Janusz Mączka

Uniwersytet Papieski Jana Pawła II w Krakowie, Wydział Filozoficzny

(The Pontifical University of John Paul II in Krakow, Faculty of Philosophy, Poland)

Centrum Kopernika Badań Interdyscyplinarnych Uniwersytetu Jagiellońskiego, Kraków

(Copernicus Center for Interdisciplinary Studies of the Jagiellonian University, Cracow, Poland)

ORCID: https://orcid.org/0000-0001-8963-9529

januszm@sdb.krakow.pl

DOI: 10.21697/spch.2020.56.4.07
} 